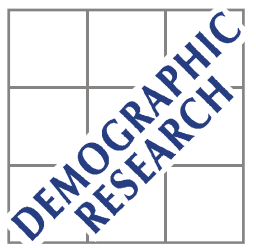

Demographic Research a free, expedited, online journal of peer-reviewed research and commentary in the population sciences published by the Max Planck Institute for Demographic Research Doberaner Strasse 114 D D-18057 Rostock · GERMANY www.demographic-research.org

DEMOGRAPHIC RESEARCH

VOLUME 6, ARTICLE 17, PAGES 469-486

PUBLISHED 28 JUNE 2002

www.demographic-research.org/Volumes/Vol6/17/

DOI: 10.4054/DemRes.2002.6.17

\title{
Seasonality of Deaths in the U.S. by Age and Cause
}

Craig A. Feinstein

(C) 2002 Max-Planck-Gesellschaft. 


\section{Table of Contents}

$1 \quad$ Introduction $\quad 470$

$2 \quad$ Analysis of seasonality by age and cause using 470

3 Variation of seasonality of deaths with respect to 478

$4 \quad$ Seasonality over the years 482

$5 \quad$ Acknowledgements $\quad 485$

References 486 


\title{
Seasonality of Deaths in the U.S. by Age and Cause
}

\author{
Craig A. Feinstein ${ }^{1}$
}

\begin{abstract}
In this paper, we analyze seasonality of deaths by age and cause in the U.S. using public use files for the years 1994 to 1998 by the methods of regression and a variation of Census Method II. We answer the following questions: For each age cohort, how much does each cause of death contribute to seasonality of deaths? What is the reason for the variation in seasonality of deaths with respect to age? We also analyze death records of Social Security Administration over a longer time period to examine how seasonality of deaths has changed since the mid-1970's. We found that in general, the degree of seasonality in deaths has decreased over time for younger cohorts and has increased over time for older cohorts.
\end{abstract}

$1 \quad$ U.S. Social Security Administration

Opinions expressed in this article are those of the author, and no official endorsement by the U.S. Social Security Administration should be inferred. 


\section{Introduction}

It is a known fact that in the U.S., the overall death rates are higher in the winter months than they are at other times of the year. However, there is little current research on this phenomenon. The most recent analysis done in the U.S. that we could find on this topic was a paper by Seretakis et al. (1997) which discussed the seasonality of mortality for coronary heart disease in the U.S. from 1937 through 1991. Earlier, Rogot, Fabsitz, and Feinleib (1976) used U.S. National Center for Health Statistics data from 1962 to 1966 to analyze seasonal patterns with respect to different causes of deaths, including determining correlations between different causes. And Rosenwaike (1966) utilized the "Census Method II" procedure to analyze the seasonality of U.S. deaths from 1951 to 1960 with respect to different causes.

In this note, we analyze the seasonality of mortality for subsets of deaths distinguished not only by cause but also by age of decedent, using death certificate data obtained from the National Center for Health Statistics for the years 1994 to 1998 . We also examine why seasonality is more prevalent in certain age groups by observing cause-seasonalities of death and distributions in causes of death with respect to age. Furthermore, using Social Security's SSI records and the death file of the Office of the Chief Actuary at the Social Security Administration from 1976 to 1999, we observe how seasonal variation in mortality has changed over the years, and whether it varies by poverty status.

\section{Analysis of Seasonality by Age and Cause Using NCHS Data}

We obtained from the NCHS CD-ROM information on everyone that died in the years 1994 to 1998, and tabulated the number of deaths in each of the sixty months within the five-year period by age group and cause. Because some months have more days than others do, we computed $a(t)$, the average number of deaths per day in month $\mathrm{t}$ for each age group and cause. Table 1 and Figure 1 show the average number of deaths per day over the five-year period. 
Table 1: $\quad$ Average Number of Deaths per Day by Age Group and Cause over the Five Year Period

\begin{tabular}{|c|c|c|c|c|c|c|c|c|c||c||}
\hline & $\begin{array}{c}\text { Cardio- } \\
\text { vascular }\end{array}$ & $\begin{array}{c}\text { Dia- } \\
\text { betes }\end{array}$ & $\begin{array}{c}\text { Diges- } \\
\text { tive }\end{array}$ & $\begin{array}{c}\text { External } \\
\text { Causes }\end{array}$ & $\begin{array}{c}\text { Infections } \\
\text { Parasitic }\end{array}$ & Kidney & $\begin{array}{c}\text { Malignant } \\
\text { Neoplasm }\end{array}$ & $\begin{array}{c}\text { Respi- } \\
\text { ratory }\end{array}$ & $\begin{array}{c}\text { Other } \\
\text { Causes }\end{array}$ \\
\hline 0 to 4 & 3 & 0 & 0 & 11 & 3 & 0 & 1 & 2 & 76 & 96 \\
\hline 5 to 9 & 0 & 0 & 0 & 5 & 1 & 0 & 1 & 0 & 3 & 10 \\
\hline 10 to 14 & 1 & 0 & 0 & 7 & 0 & 0 & 1 & 0 & 3 & 12 \\
\hline 15 to 19 & 1 & 0 & 0 & 32 & 1 & 0 & 2 & 1 & 4 & 41 \\
\hline 20 to 24 & 2 & 0 & 0 & 38 & 2 & 0 & 3 & 1 & 5 & 51 \\
\hline 25 to 29 & 4 & 1 & 0 & 34 & 7 & 0 & 4 & 1 & 6 & 57 \\
\hline 30 to 34 & 8 & 1 & 1 & 36 & 17 & 0 & 9 & 2 & 10 & 84 \\
\hline 35 to 39 & 17 & 2 & 4 & 38 & 21 & 1 & 17 & 3 & 14 & 117 \\
\hline 40 to 44 & 30 & 3 & 7 & 34 & 20 & 1 & 30 & 4 & 18 & 147 \\
\hline 45 to 49 & 48 & 5 & 8 & 27 & 14 & 1 & 49 & 5 & 21 & 178 \\
\hline 50 to 54 & 67 & 7 & 8 & 20 & 9 & 1 & 73 & 8 & 21 & 214 \\
\hline 55 to 59 & 90 & 9 & 8 & 16 & 7 & 2 & 100 & 13 & 24 & 269 \\
\hline 60 to 64 & 133 & 13 & 8 & 14 & 7 & 3 & 140 & 24 & 32 & 374 \\
\hline 65 to 69 & 201 & 19 & 9 & 15 & 9 & 5 & 197 & 44 & 48 & 547 \\
\hline 70 to 74 & 295 & 25 & 10 & 18 & 11 & 8 & 241 & 69 & 72 & 749 \\
\hline 75 to 79 & 379 & 27 & 8 & 20 & 13 & 10 & 233 & 89 & 100 & 879 \\
\hline 80 to 84 & 446 & 25 & 6 & 20 & 13 & 12 & 190 & 97 & 125 & 934 \\
\hline 85 to 89 & 428 & 18 & 4 & 17 & 12 & 11 & 119 & 84 & 125 & 818 \\
\hline 90 to 94 & 293 & 9 & 2 & 10 & 7 & 7 & 51 & 53 & 86 & 518 \\
\hline 95 to 99 & 118 & 3 & 1 & 3 & 3 & 3 & 13 & 21 & 35 & 200 \\
\hline 100 to 104 & 26 & 0 & 0 & 1 & 0 & 1 & 2 & 5 & 8 & 43 \\
\hline 105 to 109 & 3 & 0 & 0 & 0 & 0 & 0 & 0 & 1 & 1 & 5 \\
\hline \hline All Ages & 2593 & 167 & 84 & 416 & 177 & 66 & 1476 & 527 & 837 & 6343 \\
\hline
\end{tabular}

Figure 1: $\quad$ Average Number of Deaths per Day

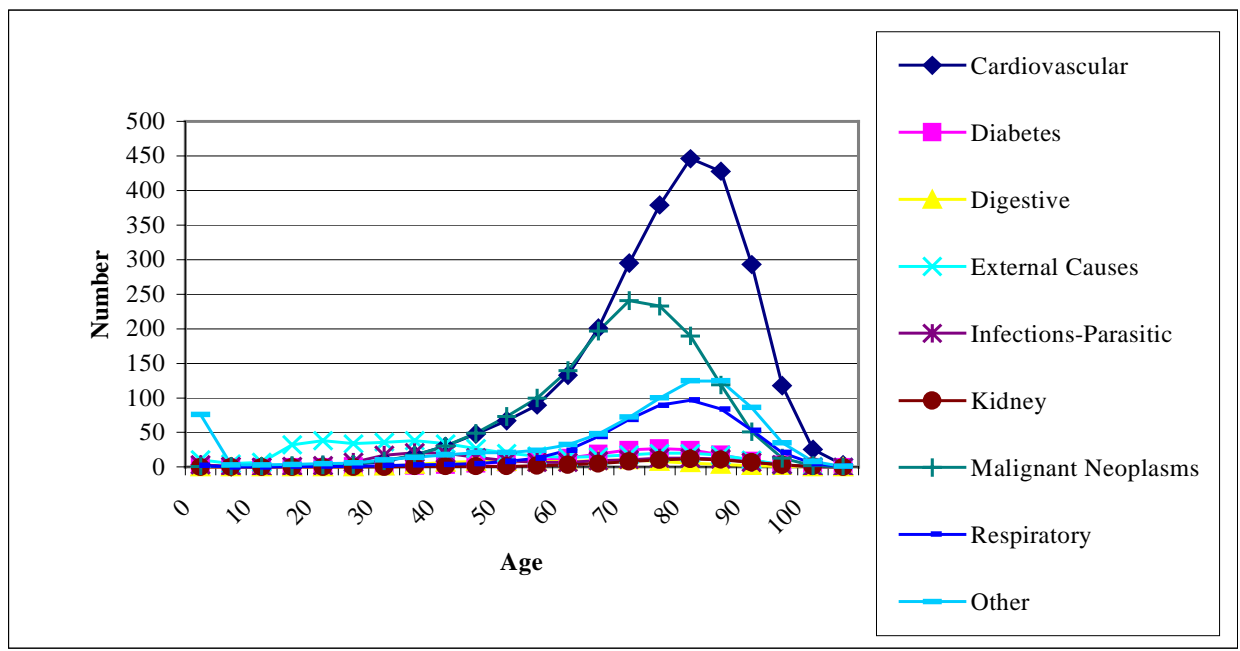


Using the "X-11 Variation of Census Method II", a modification of "Census Method II", we measured seasonality of deaths. This procedure is an elaboration of a movingaverage method: First, a centered, 12-term moving average $c(t)$ is applied to $a(t)$. The algorithm proceeds by attempting to improve the estimation of the seasonal component, $a(t) / c(t)$, by smoothing the irregular components and extreme values to obtain $s(t)$. If $s(t)$ was not significant at the $1 \%$ level, we set $s(t)=1$. We defined seasonality as

$$
s=\left[\max _{\mathrm{t}=1,2, \ldots, 12}\left\{\sum_{k=0}^{n-1} s(t+12 k)\right\} / \min _{\mathrm{t}=1,2, \ldots, 12}\left\{\sum_{k=0}^{n-1} s(t+12 k)\right\}\right]-1
$$

where $\mathrm{n}$ is the number of years of observation, here 5, obtaining the following results for age group and cause cohorts:

Table 2: $\quad$ Seasonality of Deaths for Each Age Group and Cause Cohort, Using the X-11 Variation of the Census Method II

\begin{tabular}{|c|c|c|c|c|c|c|c|c|c||c|}
\hline & $\begin{array}{c}\text { Cardio- } \\
\text { vascular }\end{array}$ & $\begin{array}{c}\text { Dia- } \\
\text { betes }\end{array}$ & $\begin{array}{c}\text { Diges- } \\
\text { tive }\end{array}$ & $\begin{array}{c}\text { External } \\
\text { Causes }\end{array}$ & $\begin{array}{c}\text { Infections } \\
\text { Parasitic }\end{array}$ & Kidney & $\begin{array}{c}\text { Malignant } \\
\text { Neoplasm }\end{array}$ & $\begin{array}{c}\text { Respi- } \\
\text { ratory }\end{array}$ & Other & $\begin{array}{c}\text { All } \\
\text { Causes }\end{array}$ \\
\hline 0 to 4 & 0.00 & 0.00 & 0.00 & 0.34 & 0.31 & 0.00 & 0.00 & 1.88 & 0.10 & 0.07 \\
\hline 5 to 9 & 0.00 & 0.00 & 0.00 & 0.96 & 0.00 & 0.00 & 0.00 & 1.21 & 0.52 & 0.39 \\
\hline 10 to 14 & 0.00 & 0.00 & 0.00 & 0.86 & 0.92 & 0.00 & 0.00 & 0.00 & 0.27 & 0.34 \\
\hline 15 to 19 & 0.00 & 0.00 & 0.00 & 0.34 & 0.94 & 0.00 & 0.00 & 0.00 & 0.00 & 0.22 \\
\hline 20 to 24 & 0.00 & 0.00 & 0.00 & 0.25 & 0.51 & 0.00 & 0.00 & 0.76 & 0.26 & 0.16 \\
\hline 25 to 29 & 0.00 & 0.00 & 0.00 & 0.23 & 0.20 & 0.00 & 0.00 & 0.53 & 0.19 & 0.12 \\
\hline 30 to 34 & 0.00 & 0.00 & 0.00 & 0.18 & 0.13 & 0.00 & 0.00 & 0.78 & 0.00 & 0.07 \\
\hline 35 to 39 & 0.00 & 0.00 & 0.00 & 0.16 & 0.08 & 0.00 & 0.13 & 0.92 & 0.19 & 0.07 \\
\hline 40 to 44 & 0.17 & 0.29 & 0.30 & 0.13 & 0.00 & 0.00 & 0.00 & 0.90 & 0.18 & 0.08 \\
\hline 45 to 49 & 0.14 & 0.34 & 0.00 & 0.11 & 0.16 & 0.00 & 0.00 & 0.75 & 0.12 & 0.09 \\
\hline 50 to 54 & 0.15 & 0.28 & 0.15 & 0.16 & 0.28 & 0.00 & 0.07 & 0.74 & 0.17 & 0.13 \\
\hline 55 to 59 & 0.23 & 0.30 & 0.26 & 0.00 & 0.20 & 0.00 & 0.00 & 0.76 & 0.19 & 0.14 \\
\hline 60 to 64 & 0.23 & 0.25 & 0.22 & 0.12 & 0.26 & 0.00 & 0.05 & 0.79 & 0.25 & 0.17 \\
\hline 65 to 69 & 0.25 & 0.23 & 0.19 & 0.00 & 0.25 & 0.25 & 0.04 & 0.79 & 0.26 & 0.20 \\
\hline 70 to 74 & 0.29 & 0.23 & 0.20 & 0.09 & 0.30 & 0.32 & 0.04 & 0.74 & 0.29 & 0.22 \\
\hline 75 to 79 & 0.31 & 0.27 & 0.30 & 0.00 & 0.41 & 0.30 & 0.06 & 0.83 & 0.31 & 0.27 \\
\hline 80 to 84 & 0.34 & 0.31 & 0.25 & 0.24 & 0.44 & 0.42 & 0.08 & 0.92 & 0.37 & 0.33 \\
\hline 85 to 89 & 0.36 & 0.31 & 0.32 & 0.26 & 0.58 & 0.47 & 0.09 & 1.10 & 0.41 & 0.39 \\
\hline 90 to 94 & 0.39 & 0.35 & 0.31 & 0.38 & 0.51 & 0.42 & 0.10 & 1.22 & 0.43 & 0.42 \\
\hline 95 to 99 & 0.39 & 0.67 & 0.00 & 0.42 & 0.79 & 0.45 & 0.16 & 1.47 & 0.52 & 0.50 \\
\hline 100 to 104 & 0.45 & 0.00 & 0.00 & 0.00 & 0.94 & 0.00 & 0.39 & 1.14 & 0.60 & 0.48 \\
\hline 105 to 109 & 0.58 & 0.00 & 0.00 & 0.00 & 0.00 & 0.00 & 0.00 & 1.57 & 0.00 & 0.63 \\
\hline \hline All Ages & 0.31 & 0.25 & 0.18 & 0.13 & 0.23 & 0.36 & 0.04 & 0.92 & 0.29 & 0.25 \\
\hline
\end{tabular}


Figure 2: Seasonalities by Age and Cause Using the X-11 Method (Major Causes Only)

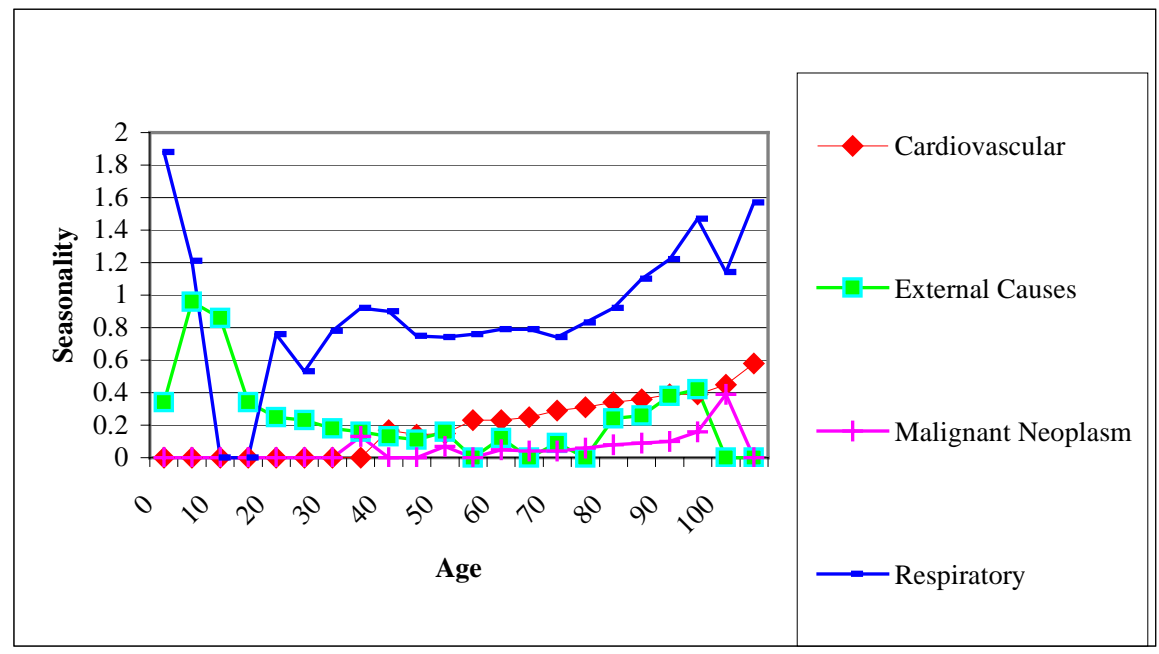

A paper by Mackenbach, Kunst, and Looman entitled "Seasonal variation in mortality in The Netherlands" (1992) describes another procedure which measures seasonality in deaths by utilizing non-linear regression. Using this procedure, for each age group and cause, we performed a least squares fit with the equation,

$$
\log a(t)=\log m+\beta\left(t-t_{0}\right)
$$

where $a(t)$ is the average number of deaths per day in month $t, m$ is the average number of deaths per day for the five year period, and $t_{0}$ is the midpoint between the start of 1994 and the end of 1998 . We added a term to measure seasonality to the equation, and using the Levenberg-Marquardt algorithm on the software package SAS ${ }^{\mathrm{TM}}$, we performed another least squares fit using:

$$
\log a(t)=\log m+\beta\left(t-t_{0}\right)+\gamma_{1} \cos \left(2 \pi\left(t-\tau_{1}\right)\right)
$$

If the added term was not statistically significant at a $1 \%$ level (using analysis of variance with the F-test), we assumed that there was negligible seasonality of deaths present in the cohort. But if the added term was significant, we assumed that there was seasonality present in the cohort, and we subsequently added the 
terms $\gamma_{k} \cos \left(2 \pi \cdot k \cdot\left(t-\tau_{k}\right)\right)$ where $\mathrm{k}=2,3$, etc. to the equation until $\mathrm{k}=5$ or in which the added term was not statistically significant at a $1 \%$ level. We computed the maximum and minimum with respect to time of the expression,

$$
s(t)=\exp \left[\sum_{k=1}^{n} \gamma_{k} \cdot \cos \left(2 \pi\left(t-\tau_{k}\right)\right)\right]
$$

(where $\mathrm{n}$ is the number of added cosine terms) which is an estimate of the seasonal component of the estimated number of deaths per day in each month, $t$. We define seasonality as $s=[\max s(t) / \min s(t)]-1$. Table 3 and Figure 3 display the seasonality of each cohort using this non-linear regression method:

Table 3: $\quad$ Seasonality of Deaths for Each Age Group and Cause Cohort, Using the Non-Linear Regression Procedure

\begin{tabular}{|c|c|c|c|c|c|c|c|c||c||c|}
\hline & $\begin{array}{c}\text { Cardio- } \\
\text { vascular }\end{array}$ & $\begin{array}{c}\text { Dia- } \\
\text { betes }\end{array}$ & $\begin{array}{c}\text { Diges- } \\
\text { tive }\end{array}$ & $\begin{array}{c}\text { External } \\
\text { Causes }\end{array}$ & $\begin{array}{c}\text { Infections- } \\
\text { Parasitic }\end{array}$ & Kidney & $\begin{array}{c}\text { Malignant } \\
\text { Neoplasm }\end{array}$ & $\begin{array}{c}\text { Respi- } \\
\text { ratory }\end{array}$ & $\begin{array}{c}\text { Other } \\
\text { Causes }\end{array}$ \\
\hline 0 to 4 & 0.00 & 0.00 & 0.00 & 0.33 & 0.22 & 0.00 & 0.00 & 1.72 & 0.06 & 0.05 \\
\hline 5 to 9 & 0.00 & 0.00 & 0.00 & 0.85 & 0.00 & 0.00 & 0.00 & 0.91 & 0.30 & 0.34 \\
\hline 10 to 14 & 0.00 & 0.00 & 0.00 & 0.81 & 0.51 & 0.00 & 0.00 & 0.00 & 0.21 & 0.32 \\
\hline 15 to 19 & 0.00 & 0.00 & 0.00 & 0.30 & 0.73 & 0.00 & 0.00 & 0.00 & 0.14 & 0.22 \\
\hline 20 to 24 & 0.00 & 0.57 & 0.00 & 0.22 & 0.00 & 0.00 & 0.00 & 0.44 & 0.00 & 0.16 \\
\hline 25 to 29 & 0.00 & 0.00 & 0.00 & 0.22 & 0.00 & 0.00 & 0.00 & 0.29 & 0.13 & 0.11 \\
\hline 30 to 34 & 0.00 & 0.25 & 0.00 & 0.20 & 0.00 & 0.00 & 0.00 & 0.51 & 0.00 & 0.00 \\
\hline 35 to 39 & 0.07 & 0.00 & 0.00 & 0.15 & 0.00 & 0.00 & 0.00 & 0.59 & 0.08 & 0.00 \\
\hline 40 to 44 & 0.12 & 0.19 & 0.17 & 0.11 & 0.00 & 0.28 & 0.00 & 0.68 & 0.11 & 0.04 \\
\hline 45 to 49 & 0.10 & 0.16 & 0.00 & 0.08 & 0.00 & 0.00 & 0.00 & 0.59 & 0.08 & 0.08 \\
\hline 50 to 54 & 0.15 & 0.23 & 0.11 & 0.00 & 0.00 & 0.00 & 0.03 & 0.68 & 0.15 & 0.10 \\
\hline 55 to 59 & 0.18 & 0.26 & 0.21 & 0.00 & 0.17 & 0.00 & 0.00 & 0.69 & 0.20 & 0.13 \\
\hline 60 to 64 & 0.22 & 0.17 & 0.16 & 0.11 & 0.18 & 0.20 & 0.03 & 0.73 & 0.19 & 0.15 \\
\hline 65 to 69 & 0.22 & 0.20 & 0.14 & 0.00 & 0.17 & 0.17 & 0.03 & 0.65 & 0.20 & 0.16 \\
\hline 70 to 74 & 0.25 & 0.20 & 0.17 & 0.12 & 0.24 & 0.22 & 0.03 & 0.64 & 0.24 & 0.19 \\
\hline 75 to 79 & 0.27 & 0.23 & 0.24 & 0.05 & 0.32 & 0.27 & 0.04 & 0.68 & 0.27 & 0.23 \\
\hline 80 to 84 & 0.30 & 0.25 & 0.13 & 0.14 & 0.33 & 0.32 & 0.05 & 0.74 & 0.33 & 0.28 \\
\hline 85 to 89 & 0.32 & 0.27 & 0.22 & 0.21 & 0.42 & 0.38 & 0.07 & 0.83 & 0.36 & 0.33 \\
\hline 90 to 94 & 0.33 & 0.29 & 0.23 & 0.29 & 0.40 & 0.35 & 0.08 & 0.95 & 0.38 & 0.36 \\
\hline 95 to 99 & 0.34 & 0.38 & 0.30 & 0.27 & 0.49 & 0.38 & 0.12 & 1.05 & 0.43 & 0.40 \\
\hline 100 to 104 & 0.39 & 0.00 & 0.00 & 0.46 & 0.00 & 0.00 & 0.00 & 0.93 & 0.43 & 0.43 \\
\hline 105 to 109 & 0.48 & 0.00 & 0.00 & 0.00 & 0.00 & 0.00 & 0.00 & 1.37 & 0.38 & 0.54 \\
\hline \hline All Ages & 0.27 & 0.24 & 0.14 & 0.13 & 0.17 & 0.28 & 0.04 & 0.74 & 0.25 & 0.21 \\
\hline
\end{tabular}


Figure 3: $\quad$ Seasonalities by Age and Cause Using Regression (Major Causes Only)



We can ask what causes of death contribute the most to the overall seasonality of deaths, in the period 1994 to 1998? To answer the question, for each age group i and cause $\mathrm{j}$ we calculated the seasonality of deaths in age group $\mathrm{i}$ excluding those who died of cause $\mathrm{j}$. We then compared these to the seasonality of deaths for each age group $\mathrm{i}$, obtaining the following: 
Table 4: $\quad$ Percentage Change in Seasonality in Each Age Group when Each Cause Is Removed, Using X-11 Method

\begin{tabular}{|c|c|c|c|c|c|c|c|c|c|}
\hline & $\begin{array}{l}\text { Cardio- } \\
\text { vascular }\end{array}$ & $\begin{array}{l}\text { Dia- } \\
\text { betes }\end{array}$ & $\begin{array}{l}\text { Diges- } \\
\text { tive }\end{array}$ & $\begin{array}{l}\text { External } \\
\text { Causes }\end{array}$ & $\begin{array}{c}\text { Infections - } \\
\text { Parasitic }\end{array}$ & Kidney & $\begin{array}{l}\text { Malignant } \\
\text { Neoplasm }\end{array}$ & $\begin{array}{l}\text { Respi- } \\
\text { ratory }\end{array}$ & Other \\
\hline 0 to 4 & $-2 \%$ & $0 \%$ & $0 \%$ & $67 \%$ & $-4 \%$ & $2 \%$ & $2 \%$ & $-24 \%$ & $74 \%$ \\
\hline 5 to 9 & $7 \%$ & $0 \%$ & $0 \%$ & $-24 \%$ & $9 \%$ & $-1 \%$ & $23 \%$ & $5 \%$ & $37 \%$ \\
\hline 10 to 14 & $9 \%$ & $1 \%$ & $1 \%$ & $-19 \%$ & $4 \%$ & $0 \%$ & $10 \%$ & $5 \%$ & $52 \%$ \\
\hline 15 to 19 & $7 \%$ & $1 \%$ & $0 \%$ & $-100 \%$ & $4 \%$ & $0 \%$ & $5 \%$ & $3 \%$ & $27 \%$ \\
\hline 20 to 24 & $6 \%$ & $4 \%$ & $-1 \%$ & $17 \%$ & $5 \%$ & $0 \%$ & $12 \%$ & $1 \%$ & $16 \%$ \\
\hline 30 to 34 & $17 \%$ & $4 \%$ & $0 \%$ & $87 \%$ & $48 \%$ & $-3 \%$ & $-6 \%$ & $3 \%$ & $7 \%$ \\
\hline 35 to 39 & $4 \%$ & $-2 \%$ & $-4 \%$ & $48 \%$ & $8 \%$ & $0 \%$ & $24 \%$ & $-11 \%$ & $-19 \%$ \\
\hline 40 to 44 & $-6 \%$ & $-6 \%$ & $-6 \%$ & $52 \%$ & $-20 \%$ & $-2 \%$ & $32 \%$ & $-17 \%$ & $-4 \%$ \\
\hline 45 to 49 & $-6 \%$ & $-2 \%$ & $3 \%$ & $28 \%$ & $6 \%$ & $-1 \%$ & $29 \%$ & $-24 \%$ & $-4 \%$ \\
\hline 50 to 54 & $-13 \%$ & $-5 \%$ & $1 \%$ & $8 \%$ & $-11 \%$ & $0 \%$ & $34 \%$ & $-18 \%$ & $-3 \%$ \\
\hline 55 to 59 & $-23 \%$ & $-4 \%$ & $-1 \%$ & $11 \%$ & $0 \%$ & $0 \%$ & $45 \%$ & $-17 \%$ & $0 \%$ \\
\hline 65 to 69 & $-17 \%$ & $-1 \%$ & $0 \%$ & $2 \%$ & $-1 \%$ & $-1 \%$ & $53 \%$ & $-24 \%$ & $-4 \%$ \\
\hline 70 to 74 & $-22 \%$ & $0 \%$ & $0 \%$ & $2 \%$ & $-1 \%$ & $0 \%$ & $52 \%$ & $-21 \%$ & $-4 \%$ \\
\hline 75 to 79 & $-8 \%$ & $0 \%$ & $0 \%$ & $1 \%$ & $-1 \%$ & $0 \%$ & $36 \%$ & $-23 \%$ & $-1 \%$ \\
\hline 80 to 84 & $-1 \%$ & $0 \%$ & $0 \%$ & $1 \%$ & $-1 \%$ & $0 \%$ & $24 \%$ & $-18 \%$ & $-3 \%$ \\
\hline 85 to 89 & $8 \%$ & $0 \%$ & $0 \%$ & $1 \%$ & $-1 \%$ & $0 \%$ & $16 \%$ & $-18 \%$ & $-1 \%$ \\
\hline 90 to 94 & $13 \%$ & $1 \%$ & $0 \%$ & $1 \%$ & $0 \%$ & $0 \%$ & $11 \%$ & $-18 \%$ & $3 \%$ \\
\hline 95 to 99 & $30 \%$ & $0 \%$ & $0 \%$ & $1 \%$ & $-1 \%$ & $0 \%$ & $6 \%$ & $-17 \%$ & $-1 \%$ \\
\hline 100 to 104 & $44 \%$ & $0 \%$ & $1 \%$ & $0 \%$ & $1 \%$ & $-1 \%$ & $3 \%$ & $-16 \%$ & $10 \%$ \\
\hline 105 to 109 & $64 \%$ & $-1 \%$ & $0 \%$ & $-2 \%$ & $-5 \%$ & $-1 \%$ & $-2 \%$ & $-19 \%$ & $15 \%$ \\
\hline
\end{tabular}

Figure 4: $\quad$ Percentage Change in Seasonality (as Measured by the X-11 Method) when Cause Is Removed

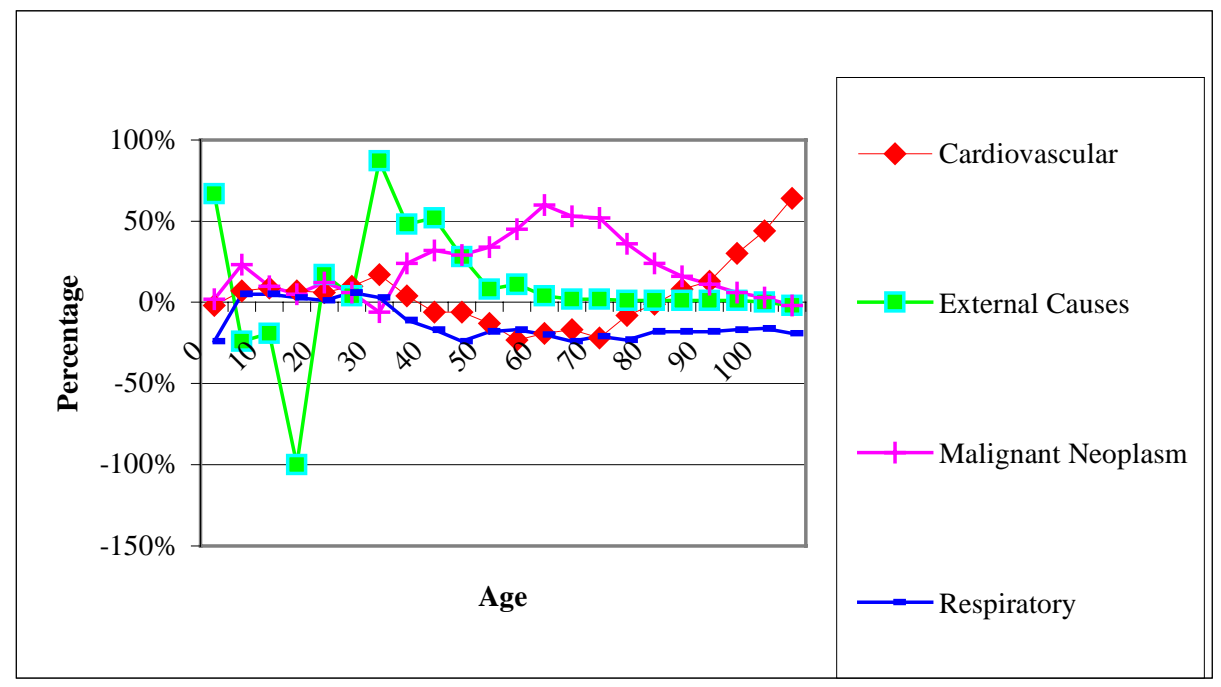


Table 5: $\quad$ Percentage Change in Seasonality in Each Age Group when Each Cause Is Removed, Using Regression

\begin{tabular}{|c|c|c|c|c|c|c|c|c|c|}
\hline & $\begin{array}{c}\text { Cardio- } \\
\text { vascular }\end{array}$ & $\begin{array}{c}\text { Dia- } \\
\text { betes }\end{array}$ & $\begin{array}{l}\text { Diges- } \\
\text { tive }\end{array}$ & $\begin{array}{l}\text { External } \\
\text { Causes }\end{array}$ & $\begin{array}{c}\text { Infections - } \\
\text { Parasitic }\end{array}$ & Kidney & $\begin{array}{l}\text { Malignant } \\
\text { Neoplasm }\end{array}$ & Respiratory & Other \\
\hline 0 to 4 & $-3 \%$ & $-1 \%$ & $-2 \%$ & $63 \%$ & $-10 \%$ & $0 \%$ & $2 \%$ & $-38 \%$ & $127 \%$ \\
\hline 5 to 9 & $4 \%$ & $0 \%$ & $-1 \%$ & $-33 \%$ & $6 \%$ & $-1 \%$ & $22 \%$ & $5 \%$ & $50 \%$ \\
\hline 10 to 14 & $11 \%$ & $0 \%$ & $-1 \%$ & $-44 \%$ & $9 \%$ & $0 \%$ & $17 \%$ & $5 \%$ & $35 \%$ \\
\hline 15 to 19 & $-5 \%$ & $0 \%$ & $0 \%$ & $-52 \%$ & $4 \%$ & $-1 \%$ & $6 \%$ & $2 \%$ & $18 \%$ \\
\hline 20 to 24 & $3 \%$ & $1 \%$ & $-1 \%$ & $-14 \%$ & $0 \%$ & $0 \%$ & $7 \%$ & $2 \%$ & $0 \%$ \\
\hline 25 to 29 & $-13 \%$ & $2 \%$ & $0 \%$ & $-100 \%$ & $14 \%$ & $-1 \%$ & $12 \%$ & $3 \%$ & $-2 \%$ \\
\hline 30 to 34 & $\mathrm{~N} / \mathrm{A}$ & $\mathrm{N} / \mathrm{A}$ & N/A & N/A & N/A & $\mathrm{N} / \mathrm{A}$ & $\mathrm{N} / \mathrm{A}$ & $\mathrm{N} / \mathrm{A}$ & N/A \\
\hline 35 to 39 & $\mathrm{~N} / \mathrm{A}$ & $\mathrm{N} / \mathrm{A}$ & $\mathrm{N} / \mathrm{A}$ & $\mathrm{N} / \mathrm{A}$ & $\mathrm{N} / \mathrm{A}$ & $\mathrm{N} / \mathrm{A}$ & $\mathrm{N} / \mathrm{A}$ & $\mathrm{N} / \mathrm{A}$ & $\mathrm{N} / \mathrm{A}$ \\
\hline 40 to 44 & $-100 \%$ & $-7 \%$ & $-100 \%$ & $114 \%$ & $31 \%$ & $-3 \%$ & $20 \%$ & $-100 \%$ & $-100 \%$ \\
\hline 45 to 49 & $-14 \%$ & $-4 \%$ & $1 \%$ & $28 \%$ & $4 \%$ & $-2 \%$ & $15 \%$ & $-20 \%$ & $-3 \%$ \\
\hline 50 to 54 & $-19 \%$ & $-4 \%$ & $0 \%$ & $10 \%$ & $-3 \%$ & $-1 \%$ & $47 \%$ & $-19 \%$ & $-6 \%$ \\
\hline 55 to 59 & $-19 \%$ & $-4 \%$ & $0 \%$ & $6 \%$ & $-1 \%$ & $-1 \%$ & $49 \%$ & $-19 \%$ & $-6 \%$ \\
\hline 60 to 64 & $-24 \%$ & $-2 \%$ & $-1 \%$ & $5 \%$ & $-1 \%$ & $-1 \%$ & $68 \%$ & $-20 \%$ & $-3 \%$ \\
\hline 65 to 69 & $-17 \%$ & $-2 \%$ & $-1 \%$ & $2 \%$ & $-1 \%$ & $-1 \%$ & $50 \%$ & $-21 \%$ & $-3 \%$ \\
\hline 70 to 74 & $-21 \%$ & $-1 \%$ & $0 \%$ & $1 \%$ & $-1 \%$ & $-1 \%$ & $50 \%$ & $-20 \%$ & $-3 \%$ \\
\hline 75 to 79 & $-13 \%$ & $-1 \%$ & $0 \%$ & $1 \%$ & $-1 \%$ & $-1 \%$ & $32 \%$ & $-18 \%$ & $-2 \%$ \\
\hline 80 to 84 & $-7 \%$ & $0 \%$ & $0 \%$ & $1 \%$ & $-1 \%$ & $-1 \%$ & $24 \%$ & $-16 \%$ & $-3 \%$ \\
\hline 85 to 89 & $2 \%$ & $0 \%$ & $0 \%$ & $0 \%$ & $-1 \%$ & $-1 \%$ & $15 \%$ & $-15 \%$ & $-2 \%$ \\
\hline 90 to 94 & $10 \%$ & $0 \%$ & $0 \%$ & $0 \%$ & $0 \%$ & $0 \%$ & $10 \%$ & $-16 \%$ & $-1 \%$ \\
\hline 95 to 99 & $23 \%$ & $-1 \%$ & $0 \%$ & $0 \%$ & $-1 \%$ & $0 \%$ & $5 \%$ & $-16 \%$ & $-1 \%$ \\
\hline 100 to 104 & $24 \%$ & $0 \%$ & $0 \%$ & $0 \%$ & $0 \%$ & $0 \%$ & $3 \%$ & $-13 \%$ & $0 \%$ \\
\hline 105 to 109 & $19 \%$ & $0 \%$ & $0 \%$ & $0 \%$ & $-1 \%$ & $-2 \%$ & $1 \%$ & $-14 \%$ & $7 \%$ \\
\hline
\end{tabular}

Figure 5: $\quad$ Percentage Change in Seasonality (as Measured by Regression) when Cause Is Removed




As we can see, cardiovascular and respiratory problems are the most significant factors for the seasonality of deaths in older people, while external causes are the most significant factors in younger people. Even though a large percentage of the population dies from malignant neoplasms, this cause depresses the overall seasonality of deaths in the whole population.

Seasonal patterns of mortality usually have winter excesses but not always: We found that younger people who die of external causes are more prone to die in the summer than in the winter. However, older people who die of external causes are more prone to die in the winter than in the summer.

\section{Variation of Seasonality of Deaths with Respect to Age}

The seasonality of death varied significantly among age groups, with a standard deviation of $\sigma=0.15,71 \%$ as large as the mean $\mu=0.21$ for the non-linear regression method and a standard deviation of $\sigma=0.16,65 \%$ as large as the mean $\mu=0.25$ for the $\mathrm{X}-11$ method. A natural question to ask is what is the reason for the large variation in the seasonalities of death with respect to age? Two possible factors are the variation in cause-seasonalities of death with respect to age and the variation in the distribution of causes of deaths with respect to age. We investigated how each of these factors affected the variation in age-seasonality.

To calculate the effect of the variation in cause-seasonalities of death with respect to age, we synthesized new functions,

$$
s_{i}^{(1)}(t)=\sum_{j} n_{i j} \cdot s_{j}(t)
$$

where $n_{i j}$ is the number in age group $\mathrm{i}$ that died of cause $\mathrm{j}$ and $s_{j}(t)$ is the overall seasonality of deaths for people (in all age groups) that died of cause $\mathrm{j}$. We define seasonality of these new functions as we did before for $s_{j}(t)$. The following chart displays both $s_{i}$ and $s_{i}^{(1)}$ computed with each method. 
Table 6: $\quad$ Degree of Seasonality of Deaths with and without Variation in CauseSeasonality with Respect to Age

\begin{tabular}{|c|c|c|c|c|}
\hline Age Group & $\begin{array}{c}S_{i} \text { Computed Using } \\
\text { Nonlinear-Regression }\end{array}$ & $\begin{array}{c}S_{i}^{(1)} \text { Computed Using } \\
\text { Nonlinear-Regression }\end{array}$ & $\begin{array}{c}S_{i} \text { Computed Using the } \\
\text { X-11 Method }\end{array}$ & $\begin{array}{c}S_{i}^{(1)} \text { Computed Using } \\
\text { the X-11 Method }\end{array}$ \\
\hline 0 to 4 & 0.05 & 0.22 & 0.08 & 0.25 \\
\hline 5 to 9 & 0.34 & 0.08 & 0.39 & 0.11 \\
\hline 10 to 14 & 0.32 & 0.07 & 0.34 & 0.09 \\
\hline 15 to 19 & 0.22 & 0.07 & 0.22 & 0.08 \\
\hline 20 to 24 & 0.16 & 0.07 & 0.16 & 0.08 \\
\hline 25 to 29 & 0.11 & 0.06 & 0.07 & 0.12 \\
\hline 30 to 34 & 0.00 & 0.08 & 0.07 & 0.14 \\
\hline 35 to 39 & 0.00 & 0.10 & 0.08 & 0.15 \\
\hline 40 to 44 & 0.04 & 0.12 & 0.09 & 0.17 \\
\hline 45 to 49 & 0.08 & 0.14 & 0.13 & 0.18 \\
\hline 50 to 54 & 0.10 & 0.15 & 0.14 & 0.21 \\
\hline 55 to 59 & 0.13 & 0.16 & 0.17 & 0.23 \\
\hline 60 to 64 & 0.15 & 0.18 & 0.20 & 0.24 \\
\hline 65 to 69 & 0.16 & 0.19 & 0.22 & 0.27 \\
\hline 70 to 74 & 0.19 & 0.21 & 0.27 & 0.29 \\
\hline 75 to 79 & 0.23 & 0.23 & 0.33 & 0.31 \\
\hline 80 to 84 & 0.28 & 0.24 & 0.39 & 0.32 \\
\hline 85 to 89 & 0.33 & 0.26 & 0.42 & 0.34 \\
\hline 90 to 94 & 0.36 & 0.27 & 0.50 & 0.36 \\
\hline 95 to 99 & 0.40 & 0.28 & 0.48 & \\
\hline 100 to 104 & 0.43 & 0.29 & 0.63 & \\
\hline 105 to 109 & 0.54 & 0.30 & & \\
\hline
\end{tabular}

The variance of $s_{i}^{(1)}$ is $\sigma^{2}=0.0068$ using the non-linear regression method and $\sigma^{2}=$ 0.0088 using the $\mathrm{X}-11$ method. Then one minus the ratio of the standard deviation of $s_{i}^{(1)}$ to the standard deviation of $s_{i}$ is $45 \%$ for the non-linear regression method and $42 \%$ for the X-11 method. So we can estimate the percentage of the variation in seasonality attributable to the variation in the specific cause-seasonalities of death with respect to age as somewhere in the range of $42 \%$ to $45 \%$.

And to calculate the effect of the variation in the distribution in causes of death with respect to age, we synthesized new functions,

$$
s_{i}^{(2)}(t)=\sum_{j} n_{j} \cdot s_{i j}(t)
$$

where $n_{j}$ is the total number of people that died of cause $\mathrm{j}$ and $s_{i j}(t)$ is the seasonality of death in age group $i$ that died of cause $j$. We define seasonality of these new functions as we did before. The following chart displays both $s_{i}$ and $s_{i}^{(2)}$ computed with each method. 
Table 7: Degree of Seasonality of Deaths with and without Variation in Distribution of Causes of Death with Respect to Age

\begin{tabular}{|c|c|c|c|c|}
\hline Age Group & $\begin{array}{c}S_{i} \text { Computed Using } \\
\text { Nonlinear-Regression }\end{array}$ & $\begin{array}{c}S_{i}^{(2)} \text { Computed Using } \\
\text { Nonlinear-Regression }\end{array}$ & $\begin{array}{c}S_{i} \text { Computed Using the } \\
\text { X-11 Method }\end{array}$ & $\begin{array}{c}S_{i}^{(2)} \text { Computed Using } \\
\text { the X-11 Method }\end{array}$ \\
\hline 0 to 4 & 0.05 & 0.09 & 0.08 & 0.10 \\
\hline 5 to 9 & 0.34 & 0.07 & 0.39 & 0.11 \\
\hline 10 to 14 & 0.32 & 0.03 & 0.34 & 0.03 \\
\hline 15 to 19 & 0.22 & 0.01 & 0.22 & 0.07 \\
\hline 20 to 24 & 0.16 & 0.03 & 0.16 & 0.05 \\
\hline 25 to 29 & 0.11 & 0.03 & 0.07 & 0.05 \\
\hline 30 to 34 & 0.00 & 0.03 & 0.07 & 0.09 \\
\hline 35 to 39 & 0.00 & 0.07 & 0.08 & 0.14 \\
\hline 40 to 44 & 0.04 & 0.11 & 0.09 & 0.13 \\
\hline 45 to 49 & 0.08 & 0.09 & 0.13 & 0.18 \\
\hline 50 to 54 & 0.10 & 0.14 & 0.14 & 0.20 \\
\hline 55 to 59 & 0.13 & 0.16 & 0.17 & 0.21 \\
\hline 60 to 64 & 0.15 & 0.18 & 0.20 & 0.23 \\
\hline 65 to 69 & 0.16 & 0.18 & 0.22 & 0.31 \\
\hline 70 to 74 & 0.19 & 0.20 & 0.27 & 0.34 \\
\hline 75 to 79 & 0.23 & 0.22 & 0.33 & 0.36 \\
\hline 80 to 84 & 0.28 & 0.25 & 0.39 & 0.42 \\
\hline 85 to 89 & 0.33 & 0.29 & 0.42 & 0.41 \\
\hline 90 to 94 & 0.36 & 0.31 & 0.50 & 0.29 \\
\hline 95 to 99 & 0.40 & 0.34 & 0.48 & 0.63 \\
\hline 100 to 104 & 0.43 & 0.29 & & \\
\hline 105 to 109 & 0.54 & 0.32 & & \\
\hline
\end{tabular}

The variance of $s_{i}^{(2)}$ is $\sigma^{2}=0.012$ using the non-linear regression method and $\sigma^{2}=$ 0.0015 using the $\mathrm{X}-11$ method. Then one minus the ratio of the standard deviation of $s_{i}^{(2)}$ to the standard deviation of $s_{i}$ is $27 \%$ for the non-linear regression method and $23 \%$ for the X-11 method. So we can estimate the percentage of the variation in seasonality attributable to the variation in the distribution of causes of death with respect to age as somewhere in the range of $23 \%$ to $27 \%$.

Therefore, the variation in the seasonality of deaths with respect to age are substantially attributable to the variation in cause-seasonality with respect to age and to a lesser extent attributable to the variation in the distribution of causes of death with respect to age.

We present graphs of $s_{i}, s_{i}^{(1)}$, and $s_{i}^{(2)}$ computed using the X-11 method and regression: 
Figure 6: $\quad$ Seasonality of Deaths by Age in Real and Synthesized Cohorts Using the X-11 Method



Figure 7: $\quad$ Seasonality of Deaths by Age in Real and Synthesized Cohorts Using Regression






\section{Seasonality over the Years}

We also used Social Security's SSI records and the death file of the Office of the Chief Actuary (OCACT) at the Social Security Administration from 1976 to 1999. The OCACT death file is representative of the general population in the U.S. while the SSI death records only includes people who received supplemental security income (money from a needs based federal government program). Because the span of years in these files is so great, we did not use the non-linear regression method described earlier, since this method does not account very well for seasonality changing over time. (It only assumes a secular trend.) The following chart displays the average seasonality of deaths for each four-year period and each age group, using the X-11 method. We also calculated for each age group the correlation of single year of death with seasonality:

Table 8: $\quad$ Seasonality of Deaths from the SSI File by Years and Age Group with Correlation of Single Year of Death with Seasonality Using the X-11 Method

\begin{tabular}{|c|c|c|c|c|c|c|c|c|}
\hline Age Group & $\begin{array}{c}1976- \\
1979 \\
\end{array}$ & $\begin{array}{c}1980- \\
1983 \\
\end{array}$ & $\begin{array}{c}1984- \\
1987 \\
\end{array}$ & $\begin{array}{c}1988- \\
1991 \\
\end{array}$ & $\begin{array}{c}1992- \\
1995 \\
\end{array}$ & $\begin{array}{l}1996- \\
1999 \\
\end{array}$ & Average & Correlation \\
\hline 0 to 4 & 0.57 & 0.42 & 0.30 & 0.32 & 0.28 & 0.23 & 0.35 & -0.90 \\
\hline 5 to 9 & 0.27 & 0.39 & 0.40 & 0.38 & 0.37 & 0.45 & 0.38 & 0.70 \\
\hline 10 to 14 & 0.41 & 0.24 & 0.27 & 0.32 & 0.29 & 0.21 & 0.29 & -0.53 \\
\hline 15 to 19 & 0.19 & 0.19 & 0.15 & 0.19 & 0.23 & 0.15 & 0.18 & -0.04 \\
\hline 20 to 24 & 0.18 & 0.13 & 0.10 & 0.12 & 0.10 & 0.11 & 0.12 & -0.66 \\
\hline 25 to 29 & 0.00 & 0.00 & 0.00 & 0.00 & 0.00 & 0.00 & 0.00 & $\mathrm{~N} / \mathrm{A}$ \\
\hline 30 to 34 & 0.20 & 0.13 & 0.13 & 0.11 & 0.07 & 0.07 & 0.12 & -0.91 \\
\hline 35 to 39 & 0.13 & 0.10 & 0.10 & 0.07 & 0.06 & 0.07 & 0.09 & -0.89 \\
\hline 40 to 44 & 0.15 & 0.10 & 0.10 & 0.08 & 0.10 & 0.12 & 0.11 & -0.38 \\
\hline 45 to 49 & 0.17 & 0.12 & 0.08 & 0.11 & 0.09 & 0.11 & 0.11 & -0.62 \\
\hline 50 to 54 & 0.15 & 0.13 & 0.12 & 0.10 & 0.10 & 0.14 & 0.12 & -0.33 \\
\hline 55 to 59 & 0.18 & 0.15 & 0.12 & 0.12 & 0.12 & 0.17 & 0.14 & -0.17 \\
\hline 60 to 64 & 0.19 & 0.17 & 0.19 & 0.18 & 0.17 & 0.20 & 0.18 & 0.19 \\
\hline 65 to 69 & 0.17 & 0.18 & 0.20 & 0.19 & 0.21 & 0.24 & 0.20 & 0.89 \\
\hline 70 to 74 & 0.19 & 0.19 & 0.20 & 0.22 & 0.26 & 0.28 & 0.22 & 0.96 \\
\hline 75 to 79 & 0.24 & 0.22 & 0.22 & 0.24 & 0.23 & 0.27 & 0.24 & 0.50 \\
\hline 80 to 84 & 0.25 & 0.25 & 0.27 & 0.26 & 0.31 & 0.35 & 0.28 & 0.87 \\
\hline 85 to 89 & 0.33 & 0.28 & 0.32 & 0.31 & 0.32 & 0.41 & 0.33 & 0.60 \\
\hline 90 to 94 & 0.34 & 0.32 & 0.34 & 0.34 & 0.33 & 0.38 & 0.34 & 0.43 \\
\hline 95 to 99 & 0.37 & 0.33 & 0.35 & 0.34 & 0.35 & 0.45 & 0.37 & 0.49 \\
\hline 100 to 104 & 0.35 & 0.39 & 0.49 & 0.42 & 0.37 & 0.47 & 0.42 & 0.38 \\
\hline 105 to 109 & 0.86 & 0.68 & 0.50 & 0.57 & 0.66 & 0.82 & 0.68 & -0.06 \\
\hline
\end{tabular}


We did the same calculations for the death file of the Office of the Chief Actuary at the Social Security Administration (see Table 9).

Table 9: $\quad$ Seasonality of Deaths from the OCACT Death File by Years and Age Group with Correlation of Year of Death with Seasonality Using the X-11 Method

\begin{tabular}{|c|c|c|c|c|c|c|c|c|}
\hline Age Group & $\begin{array}{c}1976- \\
1979\end{array}$ & $\begin{array}{c}1980- \\
1983\end{array}$ & $\begin{array}{c}1984- \\
1987\end{array}$ & $\begin{array}{c}1988- \\
1991\end{array}$ & $\begin{array}{l}1992- \\
1995\end{array}$ & $\begin{array}{c}1996- \\
1999\end{array}$ & Average & Correlation \\
\hline 0 to 4 & 0.52 & 0.38 & 0.30 & 0.30 & 0.26 & 0.20 & 0.33 & -0.92 \\
\hline 5 to 9 & 0.31 & 0.30 & 0.31 & 0.34 & 0.31 & 0.30 & 0.31 & 0.13 \\
\hline 10 to 14 & 0.45 & 0.34 & 0.24 & 0.22 & 0.24 & 0.15 & 0.27 & -0.92 \\
\hline 15 to 19 & 0.43 & 0.38 & 0.25 & 0.24 & 0.22 & 0.14 & 0.27 & -0.94 \\
\hline 20 to 24 & 0.30 & 0.31 & 0.18 & 0.13 & 0.15 & 0.12 & 0.20 & -0.87 \\
\hline 25 to 29 & 0.21 & 0.23 & 0.15 & 0.10 & 0.09 & 0.11 & 0.15 & -0.85 \\
\hline 30 to 34 & 0.11 & 0.12 & 0.10 & 0.09 & 0.07 & 0.06 & 0.09 & -0.88 \\
\hline 35 to 39 & 0.07 & 0.08 & 0.07 & 0.06 & 0.05 & 0.06 & 0.06 & -0.62 \\
\hline 40 to 44 & 0.09 & 0.09 & 0.09 & 0.06 & 0.07 & 0.07 & 0.08 & -0.73 \\
\hline 45 to 49 & 0.09 & 0.07 & 0.08 & 0.08 & 0.09 & 0.11 & 0.09 & 0.71 \\
\hline 50 to 54 & 0.14 & 0.11 & 0.11 & 0.09 & 0.10 & 0.12 & 0.11 & -0.55 \\
\hline 55 to 59 & 0.15 & 0.11 & 0.11 & 0.11 & 0.12 & 0.15 & 0.13 & 0.03 \\
\hline 60 to 64 & 0.17 & 0.14 & 0.13 & 0.15 & 0.16 & 0.17 & 0.15 & 0.34 \\
\hline 65 to 69 & 0.16 & 0.15 & 0.16 & 0.16 & 0.17 & 0.19 & 0.16 & 0.76 \\
\hline 70 to 74 & 0.18 & 0.18 & 0.18 & 0.18 & 0.20 & 0.22 & 0.19 & 0.81 \\
\hline 75 to 79 & 0.21 & 0.19 & 0.20 & 0.22 & 0.24 & 0.28 & 0.22 & 0.84 \\
\hline 80 to 84 & 0.25 & 0.25 & 0.25 & 0.25 & 0.29 & 0.33 & 0.27 & 0.84 \\
\hline 85 to 89 & 0.28 & 0.26 & 0.31 & 0.32 & 0.35 & 0.38 & 0.32 & 0.92 \\
\hline 90 to 94 & 0.34 & 0.31 & 0.33 & 0.35 & 0.38 & 0.42 & 0.36 & 0.81 \\
\hline 95 to 99 & 0.41 & 0.38 & 0.39 & 0.39 & 0.45 & 0.49 & 0.42 & 0.73 \\
\hline 100 to 104 & 0.41 & 0.45 & 0.46 & 0.45 & 0.46 & 0.48 & 0.45 & 0.78 \\
\hline 105 to 109 & 0.70 & 0.62 & 0.48 & 0.61 & 0.62 & 0.61 & 0.61 & -0.23 \\
\hline
\end{tabular}

We present graphs of the average seasonality of deaths by age of the people in the SSI and OCACT death files and the correlations between seasonality and year of death for each age group: 
Figure 8: $\quad$ Average Seasonality of Deaths by Age

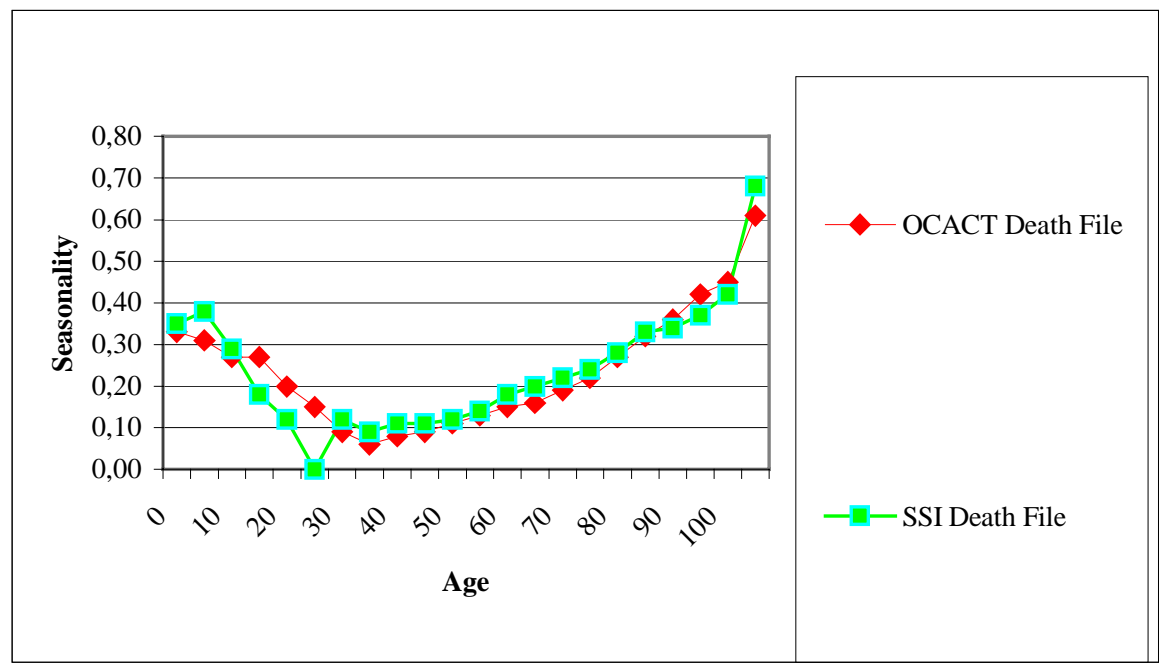

Figure 9: $\quad$ Correlation of Seasonality with Year of Death

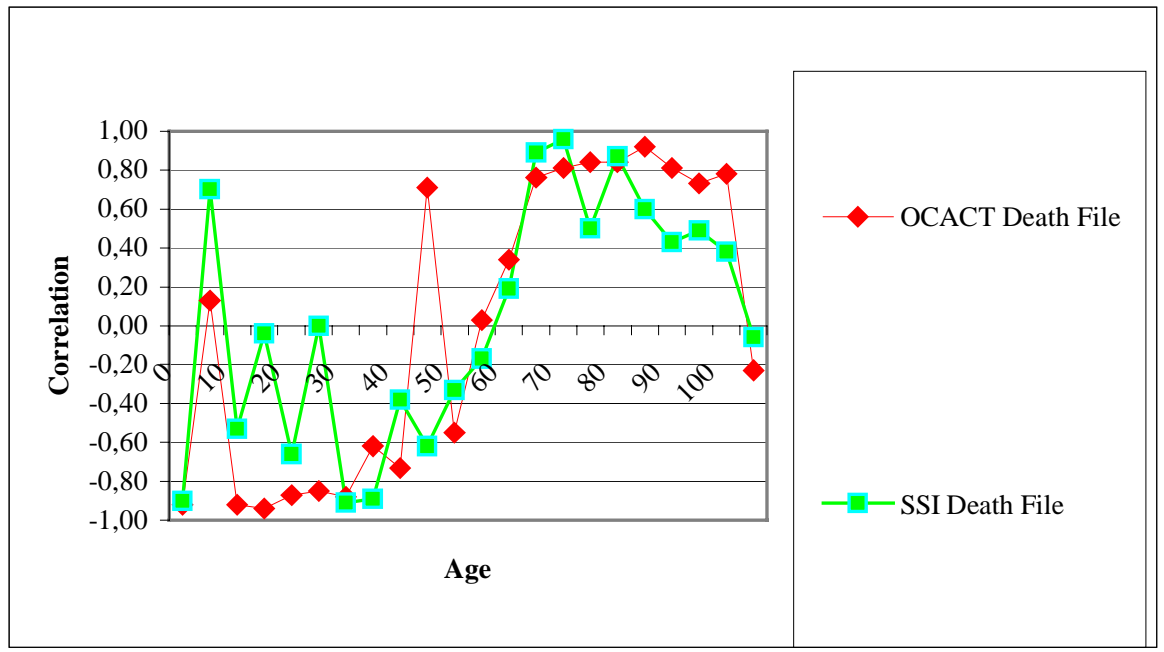


As we observed before, seasonality is greater for the more vulnerable cohorts, the young and the old. We also see that in general, seasonality of deaths decreased over time for the younger age groups and increased over time for the older age groups. Even though the people in the SSI population are generally poorer than those in the general population, the seasonalities of death are similar in each group; therefore, we have evidence that the seasonality of death phenomenon is not strongly influenced by economic status.

We now summarize our main findings:

- The X-11 variation of Census Method II and non-linear regression methods give similar measures of seasonality (for each subgroup of the population).

- The most vulnerable subgroups of the population (the young and the old) have the most seasonal variation in death.

- Respiratory and cardiovascular causes of death contribute the most to the overall seasonal excesses in the winter (for the old), while external causes of death contribute the most to the overall seasonal excesses in the summer (for the young).

- The large variation in seasonality with respect to age is attributable substantially to the variation in cause-seasonality with respect to age (42\% to $45 \%)$. It is also somewhat attributable to the variation in the distributions of causes with respect to age ( $23 \%$ to $27 \%$ ).

- The seasonalities of deaths have been increasing over the years (from 1976 to 1999) for older people and decreasing for younger people.

- There is evidence that seasonality of deaths is not heavily influenced by economic status.

\section{Acknowledgements}

I would like to thank Bert Kestenbaum for his thorough review of this paper and his many suggestions, including the idea that I investigate the topic of seasonality of mortality. Also, I thank the Max Planck Institute for Demographic Research for sponsoring and inviting me to the seminar at Duke University which was very helpful for learning about research done on seasonality of mortality in different countries. And I would like to thank Reneé Ferguson for suggesting to me the method that I used which measured the statistical significance of the added parameters in the nonlinear regression procedure. Last but not least, I would like to thank Michael Stephens for helping me with the SAS ${ }^{\mathrm{TM}}$ program calculations. 


\section{References}

Gemmell I., McLoone P., Boddy F.A., Dickinson G.J., Watt G.C.M., 2000, "Seasonal Variation in Mortality In Scotland", International Journal of Epidemiology, 29: 274-279.

Kalkstein, L. S., Valimont K. M., 1987, Climate effects on human health. In Potential effects of future climate changes on forests and vegetation, agriculture, water resources, and human health. EPA Science and Advisory Committee Monograph no. 25389, 122-52.

Laake K., Sverre J.M., 1996, "Winter Excess Mortality: A Comparison Between Norway and England Plus Wales", Age and Aging, 25:343-348.

Mackenbach J. P., Kunst A. E., Looman C. W. N., 1992, "Seasonal Variation in Mortality in The Netherlands", Journal of Epidemiology and Community Health, 46: 261-265.

Rogot E., Fabsitz R., Feinleib M., 1976, "Daily Variation in USA Mortality", American Journal of Epidemiology, Vol. 103 No. 2: 198-211.

Rogot E., Padgett S.J., 1976, "Associations of Coronary and Stroke Mortality With Temperature and Snowfall In Selected Areas of the United States", American Journal of Epidemiology, Vol. 103 No. 6: 565-575.

Rosenwaike I., 1966, "Seasonal Variation of Deaths in the United States, 1951-1960", Journal of the Amercian Statistical Association, Vol. 61: 706-717.

Seretakis D., Lagiou P., Lipworth L., Signorello LB., Rothman KJ., Trichopoulos D., 1997, "Changing Seasonality of Mortality From Coronary Heart Disease", JAMA, 278(12):1012-4.

Trudeau R., 1997, “Monthly and Daily Patterns of Death”, Statistics Canada, Catalogue 82-003-XPB, Health Reports, Vol. 9 No. 1: 44-50. 